\title{
ACCOMMODATING A TREE ASSET REGISTER OF STREET TREES IN A LOCAL GOVERNMENT AUTHORITY SETTING
}

\begin{abstract}
Purpose: The purpose of this study is to consider how a local government authority may present an asset register of street trees for use in the decision-making by the authority's stakeholders. Design/methodology/approach: Using the tenets of population density theory, urban form theory and social stratification theory, this study develops a tree asset register in a local government authority's setting that could be constructed using many different attributes to derive important information for decision-making purposes. Findings: Tree asset registers represent a critical tool in managing street trees across local government authorities. Research limitations/implications: Although the efficacy of a tree asset register may be curtailed by lack of internal audit or yearly updates, the practical consequence of a tree asset register is that local administrators may use the register to gather summarised, organised and parsimonious measures of a wide range of environmental, historical, cultural, aesthetic and scientific values of street trees. Practical implications: Tree asset registers affords ratepayers, developers, tree managers and valuers a technology to use, plan, coordinate and manage street trees to support ecosystem services. Social Implications: Tree asset registers offer planners a means to bring about sustainable change management. Originality/value: The originality of the study rests in introducing tree asset registers as a means to meet diverse strategies for street tree management by interested stakeholders.
\end{abstract}

Keywords : Street Trees, Tree Asset Registers, City of Stirling, Local Government Authorities Paper type: Research paper

Acknowledgements: The authors would like to acknowledge the generous consent given by the City of Stirling to allow the authors access to the City's street tree database.

\section{Introduction}

Street trees are an integral part of the landscape and a significant part of the heritage of an urban area (National Trusts of Australia, 2020a). Tree asset registers represent an important tool for local government authorities (LGA) in recording, reporting and keeping track of street trees. Indeed, tree asset registers provide up to date information sets about street trees for decision-making and governance by LGAs, urban dwellers, tree oversight bodies and national governments (Winram, 2019). Street trees may be perceived as natural capital assets which are defined as a stock of renewable and non-renewable assets that support ecosystem services (Leach et al., 2019), Street trees as natural capital assets yield benefits to people in terms of ecosystem services, such as contributions to human well-being including cultural services, provisioning services, and regulating and maintenance services (Haines-Young and PotschinYoung, 2018). In contrast to market prices that are used to measure produced capital (roads and buildings) and human capital ("knowledge and skills)" (Dasgupta, 2021, p. 504), social scarcity values, also known as accounting prices or shadow prices, may be used to measure natural capital. This accounting price captures the contribution an additional unit of an 
asset, good or service would make to the flow of social benefits, such as intergenerational well-being, and reflects an accommodation between the socially desirable and the socioecologically possibilities. Accounting prices strive to "reflect the true value to society of any good, service or asset" (Dasgputa, 2021, p. 501). As a consequence, many LGAs across the world are using tree asset registers to satisfy the needs of rate payers, government oversight bodies and environmentalists who seek information about the social benefits of street trees (City of Bayswater, 2020; City of Mandurah, 2020). This study introduces the idea of how tree asset registers may represent a powerful instrument in addressing an LGA's social benefit strategies to grow an urban forest, for example, by maximising canopy growth, planting more trees, retaining more trees, or better engaging the community.

\section{Figure 1 Map of Western Australia}

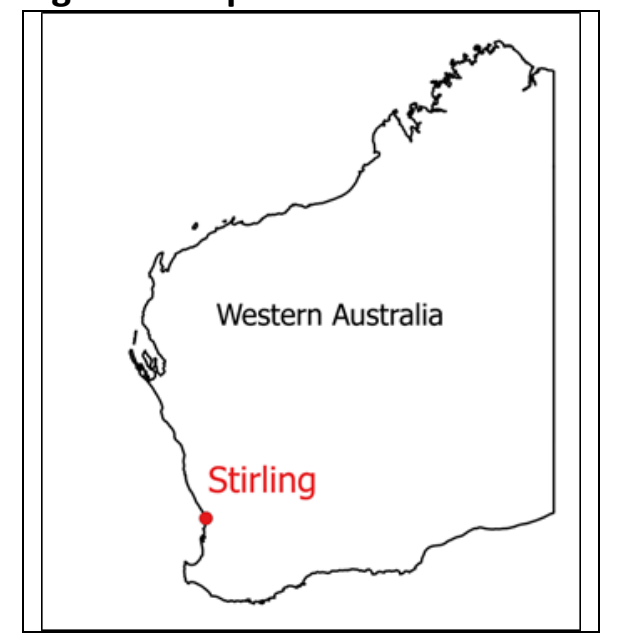

Source: Boogaerdt and Brown (2019, p. 232).

Street tree data for the year 2020 in the City of Stirling, an LGA of Western Australia (Figure 1), was provided to the authors by the City as a basis for the construction of a tree asset register. The City of Stirling (2020) has a population of 219,981 based on the 2016 census data and a landscape covering approximately 104 square kilometres, including 6.5 kilometres of coastline, 627 hectares of parks, gardens and developed reserves, 616 hectares of natural bushland, 30 suburbs, 1,118 kilometres of roads, 984 kilometres of footpaths, about 97,000 street trees and 98,000 rated properties. The City of Stirling (2018) places a high priority on shade provided by a diverse canopy of trees for natural cooling purposes and to provide habitat for wildlife. The average canopy cover urban-wide is 12.6 per, with a target of 18 per cent by 2040 (City of Stirling, 2018). The LGA's strategies to grow the City's urban forest include maximising canopy growth, planting more trees, retaining more trees, and engaging the community. Street trees represent those trees located on street verges that are controlled by the LGA. The City of Stirling does not control trees on private properties, which is where most loss of tree canopy in the City occurs. Where an LGA does have total control over trees, a tree asset register relies on identifying and assessing existing purpose-designed records of asset holdings, legal register of deeds, and statutory register of assets to make records and physical inspections of trees (French, 1994).

The study poses the following research question: How could a local government authority (LGA) construct a tree asset register to meet its diverse strategies of tree management. This 
is an important question because general communication of the benefits of street trees to the communities "has been poor" (Moffat, 2016, p. 65) and the use of a tree asset register may help a LGA communicate these benefits to its stakeholders (Gould, 2012). Information on the services and disservices of street trees, captured by tree asset registers merits attention in order to improve services and lower disservices, and communicate this to the public. The tree asset register offers an internal system of control over street trees that can be integrated into other asset management systems of an LGA. Registers have often proved effective in controlling other non-current assets. These include registers of redundant buildings (Prescott and Gronow, 1988) and property asset registers (French, 1994). The question is also important because the current information and research findings on tree asset registers is limited. To address this gap, the study shows how population density theory, urban form theory, and social stratification theory may influence the research design. Additionally, this study addresses a very important issue on tree asset management that encompasses issues on theory, valuation, sustainability, maintenance, environmental issues and security.

The study is organised as follows. Section 2 is devoted to a literature review that considers important attributes in constructing an asset tree register. Section 3 considers how a tree asset register could be constructed. Section 4 reveals the results of the study, and Section 5 presents the conclusion in light of the results.

\section{Literature Review}

The introduction and maintenance of street trees in cities, towns and villages, may be affected by natural factors, such as climate, underlying biome, soils, elevation, and slope (Pham, et al., 2017). It may also be affected by urban form, such as population density and urban morphology (Pham, et al., 2017). Urban areas are modified ecological systems that aim to satisfy human needs. The changes implied in the process of urbanization may result in strikingly different environmental conditions when compared to pre-existing ones (Camacho-Cervantes, Schondube, Castillo, \& MacGregor-Fors, 2014). In addition, the distribution of street trees may be affected by management systems, where management decisions on residential landscaping or social stratification) may be based on managerial decisions on residential, commercial and industrial areas (Pham, et al., 2017. For example, an approach by management took place recently by Christmas trees by other trees for potential harvest the following year (Urgenda, 2021). These management decisions for planting trees may vary across LGAs. Natural factors, urban form and management systems are informed by theoretical constructs. These include: population density theory, which posits that because people displace native ecosystems there is a need to restructure the urban fabric (Field, 1998); urban form theory, which avers that tree cover depends largely on the space available for planting; and social stratification theory, which asserts that residents with differential socioeconomic statuses can influence tree planting and management on public and private lands (Pham, et al., 2017). As a part of a management system, tree asset registers have the capability to produce information on natural factors, urban form and for management decisions, and thereby provide information to inform each of the three theories on the distribution of urban trees. 
The establishment of a tree asset register may benefit from the inclusion of a written statement of the significance of trees. This would enable readers to gather a sense of the trees' provisioning, regulation and maintenance services (National Trust of Australia, 2020b; Haines-Young and Potschin-Young, 2018). Here the statement, presented as an explanatory note, may clarify the type of tree that is most suitable for a street. Street trees endure vehicular pollution, trimming, soil compacting, radiative heat from surrounding buildings and variegated surfaces. As a consequence, trees that are native to the region and prosper outside the urban area may struggle in an urban environment and thus endure a lower useful life expectancy. Arborists need to make pragmatic decisions on what type of tree to plant paying particular attention to mortality rates of trees in an urban environment (Roman, et al., 2014; Bravo-Bello, et al., 2020; Lanza and Stone, 2016; Scholz, et al., 2016). Detailed analysis of a tree asset register may provide arborists with this type of information. For example, a street may benefit from deciduous trees even though they may not be native to the region. Tree diversity also needs to be considered given that a monoculture could be susceptible to pests and diseases (Bourne and Conway, 2014; Laćan and McBride, 2008). Consistent with the tenets of urban form theory, the urban environment may be regarded as a distinct environment for trees to flourish in.

In an attempt to draw attention to arboreal heritage, the New Zealand Tree Register (NZTR) identifies and registers notable, veteran and champion heritage trees as a form of public database (Gould, 2012). It uses existing records and newly submitted listings, locates heritage trees nationwide, verifies the information in the NZTR, ensures all information is accurate and in a consistent format. In addition, it encourages tree owners and citizens to submit information to the NZTR (Gould, 2012). Similarly, the Tree Register of the British Isles (TRBI) attempted "to find trees of outstanding size, vigour, shape and health, for use as parent trees in breeding programmes" (Hallett, 1989, p. 147). If a tree is used as breeding stock and its success is tracked that also forms part of data captured for the TRBI. In particular, the TRBI assembled information on form, height, location, number, planting date, species of original trees.

Moffat (2016) explains that street trees of whatever provenance should have significant aesthetic, culinary, social and psychological values for urban people. Indeed, there are considerable environmental, economic and social benefits of maintaining urban trees such as archaeological protection, biodiversity, carbon sequestration, climate flood and water protection, pollution mitigation, and soil protection (Boogaerdt and Brown, 2019). In addition, Moffat (2016) recognises that street trees may generate environmental disservices such as damage to buildings, engineered containment structures, pavements and urban infrastructure. They may also contribute to tree root invasion of drains, pipes sewers, subsidence and wildfire, emissions of volatile organic compounds (Saunders et al., 2011). It is possible for tree asset registers to include information on these potential environmental disservices.

Street trees may also generate social disservices given they may be recognised as habitats for pests and pathogens, and places of danger that promote crime and anti-social behaviour (Moffat, 2016). Other disservices include bird dropping nuisance, infringements on personal space, blotting out of light, potential for trees or branches fall on to people, and 
interference with electromagnetic signals. Recording disservices in the tree asset register may be used by an LGA to consider on notices of complaint. This type of data could also be accessible to the urban planners and arborists to use in their modelling. Street trees also bear an economic disservice as they cost money to maintain through infrastructure repair, tree replacement, pruning, and leaf fall management.

One challenge facing tree asset registers is how to capture and communicate these economic disservices to manage them (Livesley, et al. 2016). Collecting and maintaining tree data for a tree register is time consuming and costly. Saarinen, et al. (2014) suggest that although it is necessary to update tree data, "traditional map-updating procedures, such as visual interpretation of digital aerial images or field measurements using tachymeters, are either inaccurate or expensive". To overcome these difficulties, the development of laserscanning technology, such as a multi-source single-tree inventory (MS-STI), helps map trees and update tree criteria.

A tree asset register could include information on the species, height, diameter-at-breast height, and location (Boomregister, 2021; Saarinen, et al., 2014). In this way, the tree asset register could be used in urban and environmental planning, by locating old trees that are hazardous (for citizens), and monitoring biodiversity (Saarinen, et al., 2014). Tree data may be recorded on urban-planning maps (Saarinen, et al., 2014) used by many LGAs, including City of Stirling (2019), such as Intramap (2021) which is accessible for anyone on the internet and shows how tree data can be combined with other data. The Dutch city of Zwolle (Zwolle, 2021) shows only significant trees on their maps with information on the size of the tree, species, data planted and whether the tree is publicly or privately owned.

Many LGAs in Western Australia manage a significant tree register for heightened awareness of the importance of trees within the urban environment (City of Bayswater, 2020). Tree registers may play a major role in recording this information. A Significant Tree Register was established as an initiative by the City of Mandurah (2020) to protect trees of significance in the community. The Town of Victoria Park (2020) also uses a tree register to protect individual or groups of trees that are highly valued in the community, and noteworthy in terms of their: outstanding visual/aesthetic significance, botanic/scientific significance, ecological value significance, and historical, commemorative, cultural or social significance. In the early 1990s, The National Trust (WA) and The Tree Society established a Register of Significant Trees, not only to save tree specimens but also to interest the public in the value of trees generally. In this context, the National Trusts of Australia (2020b) conserves Australia's indigenous, natural and historic heritage through custody of heritage places and objects, including a national register of 2,500 significant trees that is continually updated. The purpose of the register is to capture "a wide range of environmental, historical, cultural, aesthetic and scientific value over and above the accepted benefits of an everyday tree" (National Trusts of Australia (2020c, p. 2) as a means of expressing their cultural worth in addition to their monetary value (Donovan and Butry, 2010). Although the City of Stirling does not publish a Register of Significant Trees, it claims to track, plan, manage and maintain significant trees through a policy adopted in 2016 (City of Stirling, 2020). This policy arose in response to the decline in the City's tree canopy cover and to ensure it achieved its vision for 2030 for maintaining cool, liveable suburbs. 
There are many possible attributes that may be included in a LGA's tree asset register to manage street trees. At the data collection phase, measurements of street trees may be taken. There are different ways of determining the shape and size of a tree so it is important for the purposes of data integrity that the tree register records the method used for measuring each street tree. The tree asset register may also record calculations of valuations of street trees such as those captured by the Helliwell system (Boogaerdt and Brown, 2019). In accordance with the tenets of social stratification theory, a continuously updated tree register, with updated calculations, may be helpful in achieving optimal outcomes (Roman et al., 2014). The tree asset register, for example, could continuously update important statements.

National Trusts of Australia (2020c) also advances the idea of maintaining stewardship practices for registered trees. For example, there are initiatives by councils to encourage residents to 'adopt a tree or a park' programs (City of Stirling, 2021a; 2021b). These programs encourage the promotion of adequate environmental allocation above the ground, including access to sunlight, canopy space, limited grass competition and active surface layer of organic matter (mulch) National Trusts of Australia (2020c). This information could be included in a tree register. Tree registers could also include information about adequate environmental allocation below the ground, including a street tree's compaction with soils, air, water and drainage. The combination of drought, water restrictions, and rapid export of stormwater away from the urban environment leaves the urban landscape waterstarved and can constrain tree transpiration (Coutts, White, Tapper, Beringer, \& Livesley, 2016) and reduce the cooling effect. In addition, the tree register could contain information that notes if the soil was altered or improved (Liukas, 2020). National Trusts of Australia (2020d) also advance the idea of capturing information on tree pruning, which involves the removal of dead branches for the management of aesthetics, senescence or structure. Camacho-Cervantes et al., (2014) also promote the concept of capturing information on the intangible benefits of aesthetic, historic, social or horticultural significance of street trees. An illustration of these criteria is included in the picture shown in Figure 2. This social significance may arise from focussing on tree management as human management (Davison and Kirkpatrick, 2014). The cities of Mandurah and Bayswater in Western Australia not only recognise aesthetic and historical values of significant trees but also use ecological and botanic significance. These attributes are also included in Figure 2. As well as informing a readership about street tree beauty and grace, street trees may be shown to constitute a considerable biomass of green infrastructure in cities (Davison and Kirkpatrick, 2014). Large old trees have important ecological functions (Lindenmayer et al. 2012, 2013), but they often have enormous social significance as well; therefore, protecting them for ecological reasons also supports maintenance of aesthetic, symbolic, religious, and historic values. These different kinds of values can be protected in a synergetic manner (Blicharska \& Mikusiński, 2014).

Street trees may also comprise tangible economic benefits such as the provision of firewood, fruits, fencing, timber or medicines (Shackleton, et al., 2015). Important tangible benefits of street trees include health impacts such as enhanced physical health through stress reduction and increased social cohesion and enhanced urban open space (de Vries, van Dillen, Groenewegen, and Spreeuwenberg, 2013, Klemm, Heusinkveld, Lenzholzer, Jacobs, and Van Hove, 2015;). Street trees also reduce heat islands and improve the 
thermal comfort (Brown, et al., 2014). In addition, street trees form intangible benefits such as cultural and regulating services, as illustrated in Figure 2. Examples of cultural benefits arising from trees are increased physical activity, such as walkability (Ewing, et al., 2005; Sarkar et al., 2015; Hansen, 2014;Koch, Buch-Hansen, and Fritz, 2017; Gómez et al., 2013). In looking at the historical attributes of a tree asset register, it is possible to track increases and decreases of valuations of street trees over a period of time as part of an LGA's asset management remit and growing appreciation of the benefits of street trees (Davison and Kirkpatrick, 2014). This is particularly helpful for arborists. As well as recording physical measurements and tree quality observations, some tree registers may also record socio-ecological-economic values, including the historic significance or aesthetics or economic value for local medicines. These attributes may be added to the physical data. Attributes like walkability are difficult to include in a tree register because a single street tree is unlikely to contribute to walkability. However, the tree asset register could be recorded by a GIS model if a street or suburb is walkable, taking into account the age, size and type of tree (Alhamwi, et al., 2017). In this case additional information is needed, such as the presence and condition of a footpath. This tree asset register information would be particularly useful for urban planners. As shown in Figure 2, there are many aspects of a tree register which could be drawn upon. The register published could easily be presented as a report in table form that draws information from various separate tree attributes.

\section{Figure 2 Shady park in Rockingham, WA, at the foreshore used for picnics and family} gatherings

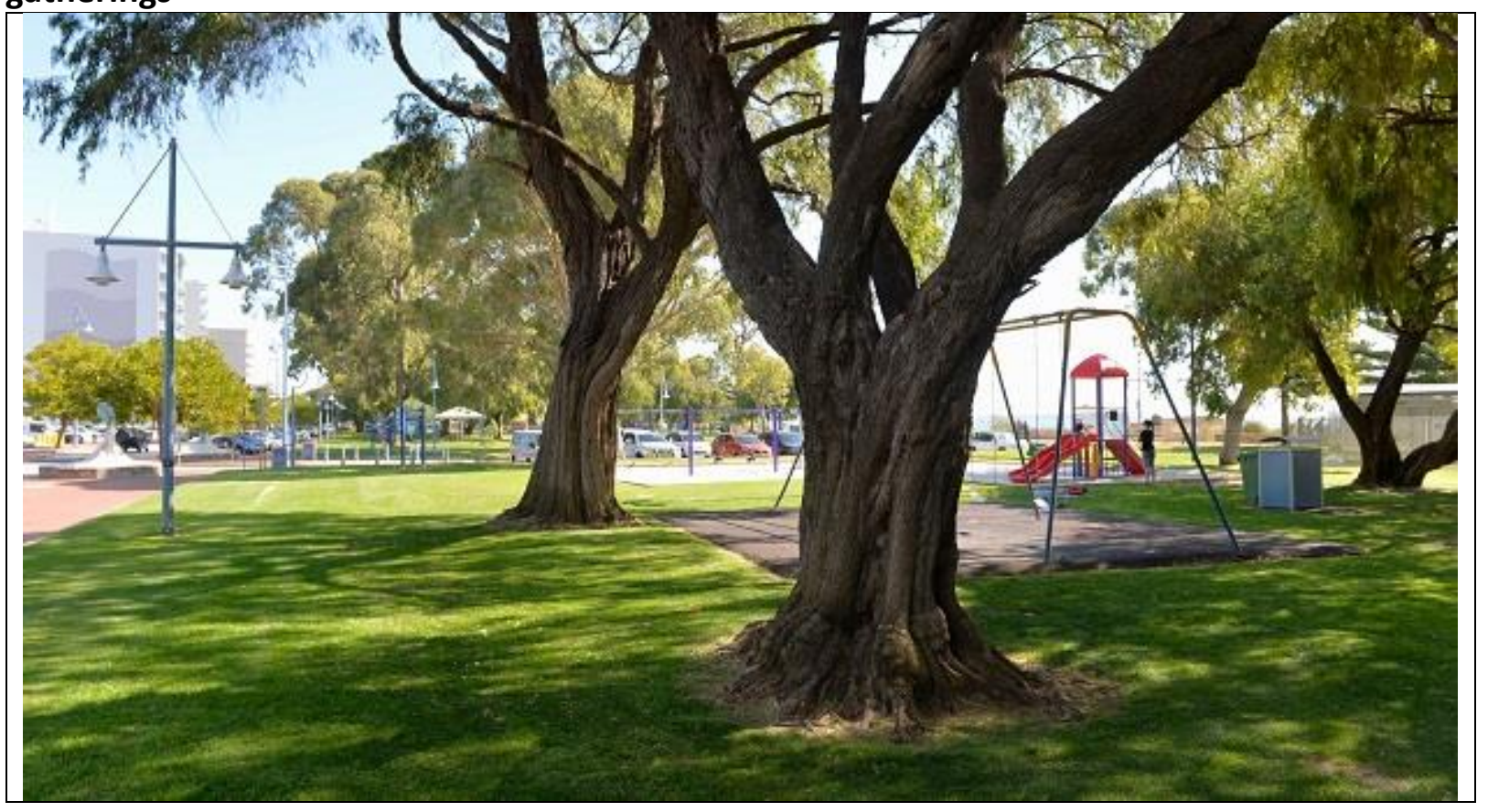

Information of the legal protection of significant trees is also advanced by the National Trusts of Australia (2020d), including local urban planning controls, state heritage laws, and state environmental laws. For example, Western Australian LGAs are required to maintain a 
Municipal Heritage Inventory ${ }^{1}$. Such an inventory could include Aboriginal cultural heritage trees which are protected by Part IIA of the Commonwealth Aboriginal and Torres Strait Islander Heritage Protection Act 1984. However, this is not mandatory. If exact date of planting is not known, tree age estimates may be acceptable in an inventory but without location details the record is unacceptable (Davison and Kirkpatrick, 2014). Shackleton et al. (2015) also consider the potential disservices of trees, which include the following. Trees may make it difficult to detect criminal behaviour (Lyytimäki and Sipilä,2009) even though there is evidence urban trees are associated with less crime (Troy, Morgan, Grove, and O'Neil-Dunne, 2012). Street trees may block sunlight, although it may be argued they may be used as a form of sunlight control (Villalba, Pattini and Corica, 2014); tree-shading may also protect bitumen (McPherson and Muchnick, 2005). In addition, street trees may be destructive causing damage to physical structures which break up pavements, and tall trees may cause maintenance problems (Lyytimäki and Sipilä,2009). Street trees may also cause allergies; attract insects, pests, spiders and birds; cause mess through leaf litter; and increase maintenance costs (Tanhuanpää, et al., 2014) including technology to reduce these costs (Gullón et al., 2015; Moore and Hughes, 2014; Saarinen et al, 2014). Maintaining healthy street trees during adverse conditions requires a trade-off between benefits and costs (Coutts et al., 2016).

As shown in Table 1, Brown and Boogaerdt (2006) also advanced the idea of exposing urban trees' historic cost, current value, net market value, replacement value and deprival value. In this context, it is important to note that the City of Melbourne maintains around 70,000 trees that have an estimated amenity value of around Australian $\$ 700$ million (Coutts et al., 2016). The total value of the 97,000 street trees of the City of Stirling is around $\$ 450$ million.

Table 1 Measurement methods of costs and values of trees

\begin{tabular}{|l|l|l|}
\hline Measurement method & Issue & Street tree application \\
\hline Historical cost & $\begin{array}{l}\text { Costs of asset are calculated on } \\
\text { original or historical cost. }\end{array}$ & $\begin{array}{l}\text { Biological change and price } \\
\text { changes make this method } \\
\text { problematic. }\end{array}$ \\
\hline Current value & $\begin{array}{l}\text { Recognizes the increasing value } \\
\text { of assets by incorporating current } \\
\text { as distinct from current value. }\end{array}$ & $\begin{array}{l}\text { Enables an assessment of the } \\
\text { existing service potential or future } \\
\text { economic benefits of street trees. }\end{array}$ \\
\hline Ret market value & $\begin{array}{l}\text { Requires self-generating and } \\
\text { regenerating assets such as street } \\
\text { trees to be measured at net } \\
\text { market value on the open market }\end{array}$ & $\begin{array}{l}\text { Service potential of street trees is } \\
\text { not readily captured by a } \\
\text { sophisticated liquid market. }\end{array}$ \\
\hline Deprival value & $\begin{array}{l}\text { Calculates a compensatory value } \\
\text { of assets. }\end{array}$ & $\begin{array}{l}\text { Studies have found it is possible to } \\
\text { approximate the value of street } \\
\text { trees based on tree attributes. }\end{array}$ \\
\hline & $\begin{array}{l}\text { Adopts a method of valuation if } \\
\text { asset is deprived. }\end{array}$ & $\begin{array}{l}\text { Enables possible suburban tree } \\
\text { evaluations given set scenarios. }\end{array}$ \\
\hline
\end{tabular}

${ }^{1}$ Most Australian states have state heritage registers to protect significant trees with heritage values. Queensland local government authorities use local government heritage registries to identify local significant trees. NSW local government authorities apply heritage values of significant trees through a heritage schedule of the Local Environmental Plan. Victorian local government authorities use planning scheme overlays, such as heritage overlays and environmental significance overlays to protect significant trees. Tasmania uses planning scheme heritage schedules of the Land Use Planning and Approvals Act 1993 to protect significant trees. Individual local council development plans may be used to identify significant trees in South Australia. 
Tree asset registers also enable LGAs to keep a record of why the urban tree was bought, its original purchase price, accumulated depreciation, and current book value, purchase date, performance and estimated useful life and to track the urban trees value over time. Street trees may have competition for space such as power lines which can have a considerable impact on the value of the tree (Boogaerdt and Brown, 2019). Again, these attributes are summarised in Figure 2. While tree values may be difficult to measure (Davison and Kirkpatrick, 2014), street tree benefits have been quantified in economic terms (McPherson et al., 2011; Pandit et al., 2013), such as the Base Value used to calculate the valuations in Helliwell (Arboricultural Association, 2020; Boogaerdt and Brown, 2019; Hellis, 2020; Helliwell, 2008) or i-Tree (2021).

Tree asset registers must be audited, as they may be used to generate indicator species audits (Winram, 2019) and assess financial and managerial performance of the LGA. The tree register should also be updated after inspections have been carried out. Tree registers could also record ecosystem benefits and services such as urban heat mitigation, stormwater runoff reduction and filtering, and noise reduction (Mullaney, Lucke, and Trueman, 2015). Data in the tree register may also provide information for modelling and assessment.

\section{Methodology - Developing a Tree Asset Register}

Using the tenets of population density theory, urban form theory and social stratification theory, the methodology of this project followed six steps in the development of a tree asset register. Step 1 gleans how a tree asset register meets the required LGA strategies for city trees. A limitation experienced in this step related to social stratification theory; it was difficult to ascertain how residents from different suburbs of the LGA directly influenced city tree planting. Nevertheless, with further research on the preferences of residents, it is possible to ascertain this strategy. Step 2 selects the tangible or intangible attributes (see Figure 3) that will help the LGA meet its city tree strategies. For example, in response to a projected population increase, a strategy may consider planting more city trees to reduce noise level. Alternatively, in response to growing urbanisation, a strategy may consider maximising canopy growth to engage the community.

Figure 3 Tangible versus In-Tangible attributes for a Tree Register 


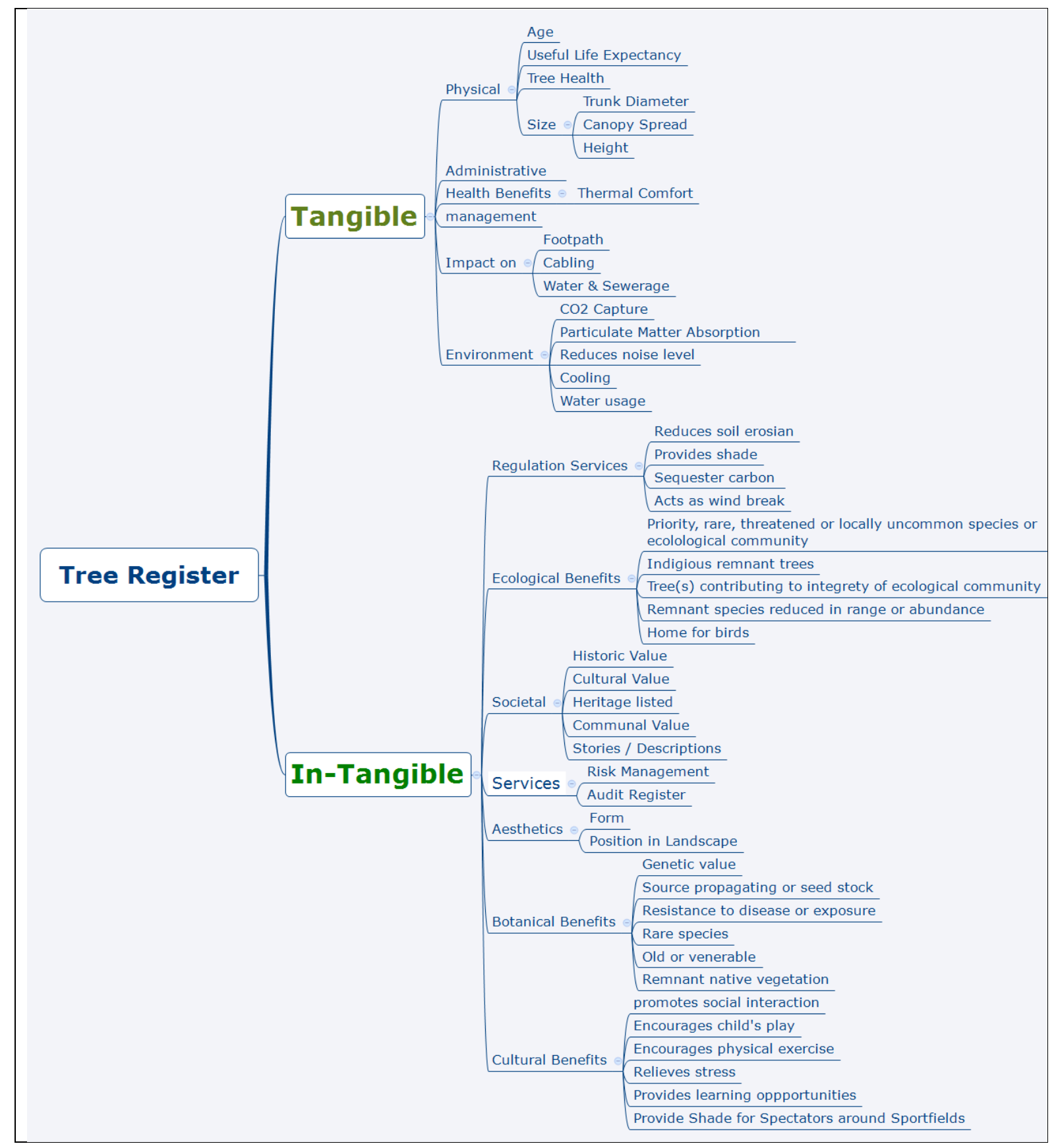

Step 3 identifies the costs, values, benefits and services of the tree register (see Figure 4). For example, consistent with theory of social stratification, a LGA differentiating itself from another LGA by growing venerable city trees may need to compare their historic value and botanical benefits of venerable tree growth with the administrative costs of maintaining this information on a tree asset register. Some of these attributes, shown in Figure 3, are more tangible than other. For example, cooling capacity or ability of $\mathrm{CO} 2$ capture can be measured as well as physical input data to calculate value according to Helliwell. These valuations do not reflect the cost of $\mathrm{CO} 2$ that the trees sequester. As the asset values in section 2 of $\$ 10,000$ for trees in Melbourne while the value for the City of Stirling is $\$ 4640$, this difference could be caused by different calculation methods and/or base values. Aesthetics and Societal values are more difficult to quantify they are like "goodwill". A tree register represents many categories of data. Yearly adjustment of tree values based on the 
consumer price index (CPI) could be done or it could be done on a let say on a five yearly basis. Before deciding which route to take it has to be investigated the differences in accuracy between $\mathrm{CPI}$ and base value. That is the uncertainty in relation to the estimate of the Helliwell base value.

Figure 4 Cost, Values, Benefits and Services of a Tree Register

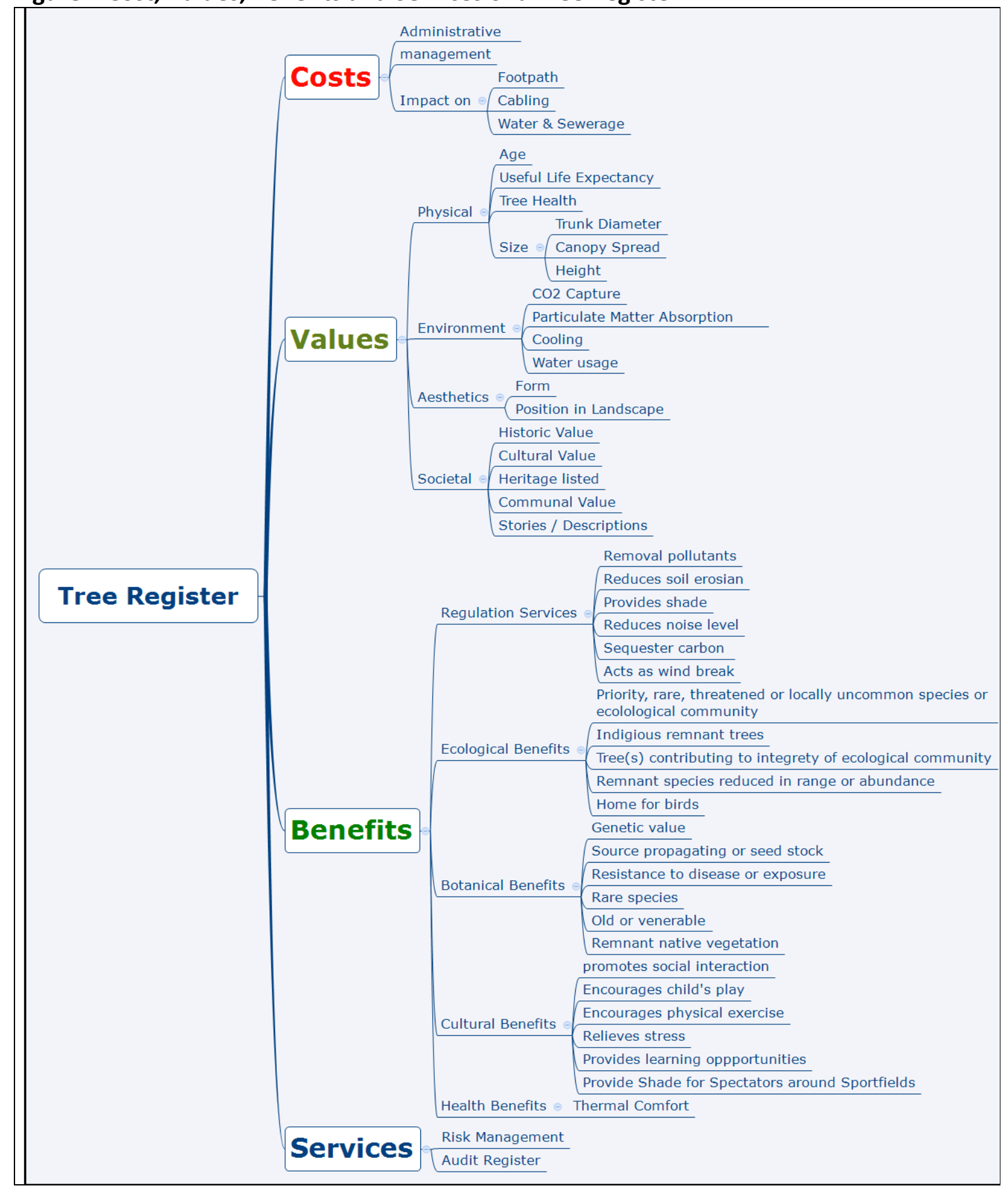

As shown in Figure 4, services may comprise risk management and audit register. In addition, services may include including cultural services, provisioning services, and regulating and maintenance services (Haines-Young and Potschin-Young, 2018). The tree 
register could be setup in such a way that financial and other modelling can be done with minimum of data, as long as that is noted when reporting. For sophisticated modelling more data would be required, there is a cost associated with collecting this extra data. Tree asset registers in combination with a sense of accounting prices (Dasgupta, 2021) may determine value of street trees. For example, as an alternative to deploying Helliwell's valuation system, some LGAs use a benefit multiplier of five times for every dollar spent on trees (McPherson, van Doorn, and de Goede, 2016). This latter method could be used because of its simplicity. However, it ignores the size aspects, quality, intangible values and benefits of the street tree as shown in Figure 4. For the tree asset register, the health of a tree could be recorded according the criteria set out by Arboriculture Australia (2020). These measures could include balanced root system, strong branches or quality of pruning. The tree asset register could also record the structure of the tree, the estimate useful life of the tree, last date of inspection, and inspector's name. As a consequence, the tree asset register could contain data about the state of trees so that appropriate management steps can be taken.

Following Saarinen et al. (2014), the use of special scanners and drone based tools could be used to record more accurately the size and shape of a tree. As currently carried out in the Netherlands, technology has made it easier to have attributes like canopy spread updated every four months (Neo, 2021). Artificial Intelligence may need to be used to analyse the data from these drone surveys since the amount of data gathered would be enormous. The collection of data, and working out how to access the data to inform the tree register is important.

Step 4 considers the accessibility of database table to inform tree asset register information (Figure 5).

Figure 5 Accessibility of Database Tables to inform Tree Register Information 


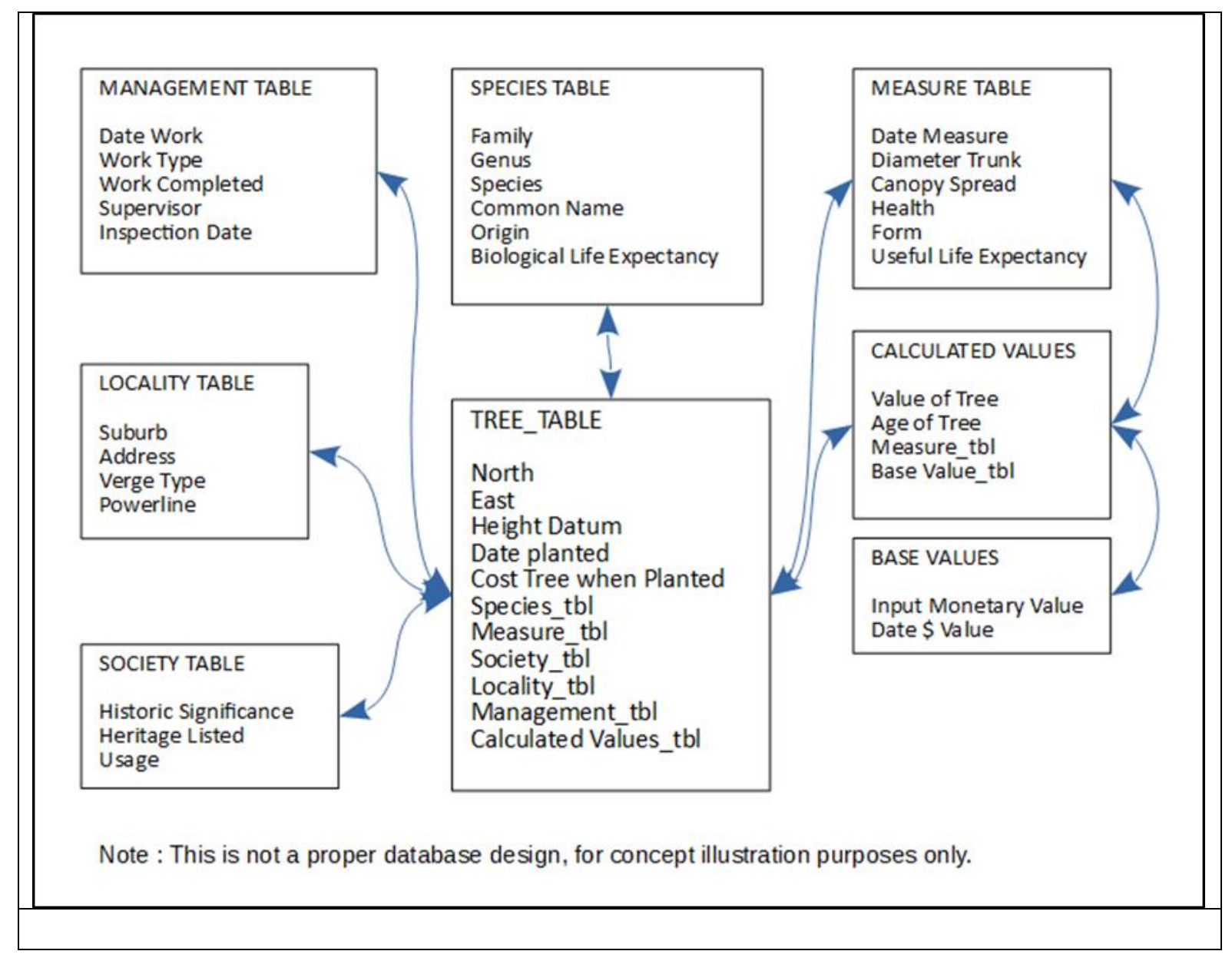

Modelling can be carried out to obtain different scenarios depending on values and assumptions used. If the tree register is properly designed according to relational database principles, historic values of trees could also be retrieved with monetary values of the time. Tree register data cannot be stored in a flat spreadsheet, because attribute relationships are complex and data integrity cannot be enforced. Therefore, there is a need for a relational database as schematically shown in Figure 5.

In Step 5, database reports can be created. Some examples are shown in Tables 2 and 3 in the next section of this paper. Forms can be used to enter new data or update existing data. Setting up a tree register is a database management issue. However, it is of vital importance that all stakeholders have input in the design to avoid one of the many very expensive examples of database design failures, because the groundwork was not explored properly. Attributes linked to a tree register do not have to be stored in the same database. For example, North and East can be used to extract address, address of verge, suburb and ward from a different database. This could be cadastral, where that information is kept up to date by a different department or even governments. Or, botanical names and common names could be extracted from a tree type database using genus and species. Both these examples are not relevant to calculate the value of a trees. However, that information is useful for the user performing data modelling or for management purposes.

Step 6 of the tree asset register design process creates a table or diagram with stakeholder relationships that encapsulates parameters not only to meet the tenets of population 
density theory, urban form theory and social stratification theory (see the following section on Discussion) but also to provide administrators with summarised, organised and parsimonious measures of a wide range of environmental, historical, cultural, aesthetic and scientific value. This is performed before the actual tree register is constructed. The methodological approach of analytic interpretation is achieved through constructing, deconstructing and reconstructing textual information for a response to the research question.

\section{Discussion}

Table 2 below shows how data could be drawn to respond to tree register questions ( $Q$ ) that could be used in at tree asset register for the purposes of the City of Stirling. A part of the table is only needed to show what can be extracted from the tree register. Thus, for example, Step 1 may ascertain that the required LGA strategy is to increase the monetary value of city trees since they were planted and compare them with canopy size. This is consistent with Q6 in Table 6. The LGA would then need to extract data from the Management table, Species table, Tree table, Measure table and Calculated Value table.

Table 2 Examples of Accessibility of Database Tables to inform Tree Register Information

\begin{tabular}{|l|l|}
\hline Q1 & List all trees that are "Queensland Box Trees" \\
\hline Data from & Tree table, Species Table \\
\hline Q2 & List all trees that are "Queensland Box Trees" and in the suburb of "Woodlands" \\
\hline Data from & Tree table, Species Table, Location table \\
\hline Q3 & $\begin{array}{l}\text { List all trees that are "Queensland Box Trees" an in the suburb of "Woodlands" with a value } \\
\text { "Greater than \$5000" }\end{array}$ \\
\hline Data from & $\begin{array}{l}\text { Tree table, Species Table, Location table, Calculated Values table that draws on Base Values } \\
\text { table }\end{array}$ \\
\hline Q4 & List species, Suburbs and Age of all heritage listed trees \\
\hline Data from & $\begin{array}{l}\text { Species table, Locality table, Society table, Tree table, Calculated Values table which calculates } \\
\text { Age from Tree table. }\end{array}$ \\
\hline Q5 & $\begin{array}{l}\text { Ascertain if the “expected tree life" based on botanical research, matches with the "useful life } \\
\text { expectancy" of street trees. }\end{array}$ \\
\hline Data from & $\begin{array}{l}\text { Species table, Locality table, Tree table, Calculated Values table which calculates Age from } \\
\text { Tree table. }\end{array}$ \\
\hline Q6 & Monetary value increase per year since planted compared with canopy size \\
\hline Data from & Management table, Species table, Tree table, Measure table, Calculated Values table \\
\hline Q7 & What is the walkability of a street \\
\hline Data from & $\begin{array}{l}\text { This question cannot be straight answered from the tree register. The register needs to be } \\
\text { accessed from and manipulated in a Geographical Information System. }\end{array}$ \\
\hline
\end{tabular}

A strategy of the LGA may be to impart information on the average value per age group of city trees. Table 3 , depicts average value per age category and the percentage of that category of the total population. Table 3 shows that the average value of the 24,419 mature trees is much higher than the 38,650 semi-mature trees. In addition, less than $0.1 \%$ of the LGA's city trees are senescent or severely declined.

Table 3 Average Value per Age Group of Street Trees

\begin{tabular}{|l|c|c|c|}
\hline Tree Age Category & $\begin{array}{c}\text { Value Age Category } \\
\text { (\$) }\end{array}$ & Number Trees & Percentage Value \\
\hline Mature & 9,852 & 24,419 & $25.0 \%$ \\
\hline
\end{tabular}




\begin{tabular}{|l|c|c|c|}
\hline Post Mature & 6,824 & 129 & $0.1 \%$ \\
\hline Semi-Mature & 4,788 & 38,650 & $39.5 \%$ \\
\hline Senescent & 2,723 & 4 & $0.0 \%$ \\
\hline Severe Decline & 3,854 & 10 & $0.0 \%$ \\
\hline Young & 918 & 34,512 & $35.3 \%$ \\
\hline
\end{tabular}

Table 4 also show some examples of information that could be extracted for the tree asset register.

Table 4 Extract from City of Stirling Tree Register: Analysing Value per Tree Type

\begin{tabular}{|l|l|c|c|c|c|}
\hline \multicolumn{1}{|c|}{ Family } & \multicolumn{1}{|c|}{ genus } & $\begin{array}{c}\text { Average } \\
\text { Tree Value } \\
\mathbf{\$}\end{array}$ & $\begin{array}{c}\text { Number } \\
\text { Trees for } \\
\text { Genus }\end{array}$ & $\begin{array}{c}\text { Percentage } \\
\text { Average } \\
\text { Value }\end{array}$ & $\begin{array}{c}\text { Percentage } \\
\text { Number } \\
\text { Trees for } \\
\text { Genus }\end{array}$ \\
\hline Casuarinaceae & Allocasuarina & 8,512 & 360 & $3.4 \%$ & $0.4 \%$ \\
\hline Casuarinaceae & Casuarina & 9,099 & 921 & $3.7 \%$ & $1.0 \%$ \\
\hline Myrtaceae & Agonis & 4,582 & 8,527 & $1.8 \%$ & $8.9 \%$ \\
\hline Myrtaceae & Angophora & 5,326 & 521 & $2.1 \%$ & $0.5 \%$ \\
\hline Myrtaceae & Callistemon & 3,304 & 13,419 & $1.3 \%$ & $13.9 \%$ \\
\hline Myrtaceae & Corymbia & 7,965 & 4,372 & $3.2 \%$ & $4.5 \%$ \\
\hline Myrtaceae & Eucalyptus & 6,072 & 11,849 & $2.4 \%$ & $12.3 \%$ \\
\hline Myrtaceae & Lophostemon & 6,689 & 15,035 & $2.7 \%$ & $15.6 \%$ \\
\hline Myrtaceae & Melaleuca & 5,694 & 3,271 & $2.3 \%$ & $3.4 \%$ \\
\hline Myrtaceae & Metrosideros & 3,295 & 771 & $1.3 \%$ & $0.8 \%$ \\
\hline Myrtaceae & Syzygium & 2,131 & 472 & $0.9 \%$ & $0.5 \%$ \\
\hline
\end{tabular}

Table 4's extract of the full query results, shows that Myrtaceae represents about 60 per cent of all urban trees with an average value of $\$ 5400$ and Causarinaceae only $1.4 \%$, value]d on average at $\$ 8900$. As these values are limited by themselves, other information from the tree register is needed to make them useful. Note that all Genus with less than 100 street trees in the urban area have been omitted in the calculation. For example, an analysis of the tree age and useful life expectancy demonstrates how a tree asset register may provide information to the City of Stirling's key strategies of growing the City's urban forest include maximising canopy growth, planting more trees, retaining more trees, and engaging the community. The tree asset register showcases how an LGA may render transparency and accountability to meet stakeholder expectations (Manetti and Toccafondi, 2012).

Accessibility to the tree register the tree data could be shared between departments, governments and other stakeholders. Ideally the public should have a way to make comments on trees or park via a map based interface. These comments could be scrutinised before they are committed to the tree register to ensure data integrity. This suggests that the issue of accessibility of a tree register to the public represents a form of sound communication that may be facilitated by freely available downloadable data.

\section{Conclusion}


The inclusion of attributes like size, shape, canopy spread of trees in a tree asset register enable LGA stakeholders to plan, control and manage tree cover. This is consistent with the tenets of urban form theory, which posits that tree cover depends largely on the space available for planting. The inclusion of aesthetic, historic, social, horticultural and ecological benefits in a tree register is consistent with the tenets of social stratification theory, which advances the idea that residents with differential socio-economic statuses may be able to influence tree planting and management on public and private lands through knowledge of specific benefits of attributes of street trees. Such attributes might also include botanic values, legal protection, current cost of the tree, and maintenance costs. It is also important a tree register is kept up to date and regularly audited. The study showed that the tree register is repository of tree related data, and consistent with the tenets of population density theory forms the input for modelling resulting in information about, for example, sun blocking by trees, walkability, or influence of trees on crime statistics. Input measurements, both tangible and intangible, may be used to calculate the value of the tree.

Input measurements may be combined to form the multiplier for the Helliwell base value to arrive at a current value for each street tree. This yearly valuation could be adjusted for Consumer Price Index for financial analysis. In a well-designed tree asset register, the integrity of its data should be ensured. However, the quality of the input data depends on accurate data. A further issue arising from introducing and maintaining tree asset registers is the cost of updating information on the attributes regularly, bearing in mind the potential costs of not updating the tree register regularly. These represent data management issues. Management procedures also need to be put in place to ensure data integrity, including regular audits and data collection quality (Roman et al., 2017).. In this context, the task to create and maintain the tree registry becomes critical the more data is collected (Tanhuanpää et al., 2014). As an internal instrument, the register attempts to capture "a wide range of environmental, historical, cultural, aesthetic and scientific value over and above the accepted benefits of an everyday tree" (National Trusts of Australia (2020c, p. 2) and thus offers fruitful information for LGA administrators.

Depending on an LGA's targets and strategies, an LGA could construct a unique tree asset register that directly addresses those targets and strategies. This study shows that a tree asset register represents a repository of tree attributes that form the input for asset management, and environmental and financial modelling. This could make comparisons of data between LGAs difficult. For that reason, state governments could impose certain minimum requirements for tree asset registers and make available resources and a basic database for those LGAs that are lagging in street tree data collection. In this way, tree asset registers could be used by state governments for their modelling. In addition, the study has shown that a tree asset register may display extensive monetary values for an interested LGA annual report readership.

\section{References}

Alhamwi, A., Medjroubi, W., Vogt, T. and Agert, C. (2017), "GIS-based urban energy systems models and tools: Introducing a model for the optimisation of flexibilisation technologies in urban areas", Applied Energy, Vol. 191, pp. 1-9. 
Arboricultural Association (2020), "What is the Helliwell system and how much is a "point"?" The Arboricultural Association, https://www.trees.org.uk/HelpAdvice/Public/What-is-the-Helliwell-system-and-how-much-is-a-po

Arboriculture Australia (2020), "Tree Care Information", https://arboriculture.org.au/abouttrees/tree-care-information

Blicharska, M., and Mikusiński, G. (2014), "Incorporating Social and Cultural Significance of Large Old Trees in Conservation Policy", Conservation Biology, Vol. 28 No. 6, pp. 1558-1567.

Boogaerdt, H., and Brown, A. (2019), "Tree-trimming impact on local government property management." Property Management, Vol. 37 No. 2, pp. 229-242.

Boomregister (2021). Boomregister tree registry organisation, The Netherlands. http://boomregister.nl/

Bourne, K. S., and Conway, T. M. (2014), "The influence of land use type and municipal context on urban tree species diversity", Urban Ecosystems, Vol. 17 No. 1, pp. 329348.

Brown, A.M. and Boogaerdt, H. (2006), "Accounting for Suburban tree information systems", Corporate Social Responsibility and Environmental Management, Vol. 13 No. 5, pp. 275-285.

Brown, H., Katscherian, D., Carter, M., and Spickett, J. (2014), “Cool communities: Urban trees, climate and health". Retrieved from http://ehia.curtin.edu.au/local/docs/CoolCommunities.pdf

Bravo-Bello, J. C., Martínez-Trinidad, T., Romero-Sanchez, M. E., Valdez-Lazalde, J. R., and Benavides-Meza, H. (2020), "The analytic hierarchy process for selection of suitable trees for Mexico city", IForest, Vo. 13 No. 6, pp. 541-547.

Camacho-Cervantes, M., Schondube, J. E., Castillo, A., and MacGregor-Fors, I. (2014), “How do people perceive urban trees? Assessing likes and dislikes in relation to the trees of a city", Urban Ecosystems, Vol. 17 No. 3, pp. 761-773. https://doi.org/10.1007/s11252-014-0343-6

City of Bayswater (2020), "Significant Tree Register", https://www.bayswater.wa.gov.au/environment-and-sustainability/streetscapes,parks-and-gardens/trees/significant-trees-register

City of Mandurah (2020), "Significant Tree Register, Recognition for Mandurah's most valuable trees", City of Mandurah, Mandurah.

City of Stirling (2021a), "Adopt a Park", https://www.stirling.wa.gov.au/leisure-andculture/attractions-and-recreation/parks-and-playgrounds

City of Stirling (2021b), "Tree Planting Programs", https://www.stirling.wa.gov.au/search?keyword=significant\%20tree

City of Stirling (2020), "Community Profile", https://www.stirling.wa.gov.au/yourcity/about-stirling/community-profile 
City of Stirling (2019), "Maps",

https://maps.stirling.wa.gov.au/intramaps97/?project=StirlingMaps

City of Stirling (2018), "Urban Forest Plan", City of Stirling, Stirling, WA.

Coutts, A. M., White, E. C., Tapper, N. J., Beringer, J., and Livesley, S. J. (2016), "Temperature and human thermal comfort effects of street trees across three contrasting street canyon environments", Theoretical and Applied Climatology, Vol. 124 No. 1-2, pp. $55-68$.

Cradduck, L. and Warren, C.M.J. (2019), "Goodwill hunting: Developing a methodology for identifying and incorporating goodwill into residential land valuations", Property Management, Vol. 37 No. 5, pp. 597-609.

Dasgupta, P. (2021), "The Economics of Biodiversity: The Dasgupta Review", HM Treasury, London.

Davison, A., and Kirkpatrick, J. B. (2014), "Risk and the Arborist in the Remaking of the Australian Urban Forest. Geographical Research", Vol. 52, No. 2, pp. 115-122.

de Vries, S., van Dillen, S. M. E., Groenewegen, P. P., and Spreeuwenberg, P., (2013), "Streetscape greenery and health: Stress, social cohesion and physical activity as mediators", Social Science \& Medicine, Vol. 94, pp. 2633.

Donovan, G. H., and Butry, D. T. (2010), "Trees in the urban: Valuing street trees in Portland, Oregon", Landscape and Urban Planning, Vol. 94 No. 2, pp. 77-83.

Ewing, R., Clemente, O., Handy, S., Brownson, R. C., and Winson, E. (2005), Measuring Urban Design Qualities Related to Walking. Active Living Research Program.

Field, B. G. (1998), "The morphology of planning in an urban laboratory", Property Management, Vol. 17, No. 2, pp. 139-156.

French, N. (1994), "Asset Registers and Asset Rents for Local Authorities: A Viable Property Management Tool", Property Management, Vol. 12 No. 3, pp. 5-23,

Gómez, F., Cueva, A. P., Valcuende, M., and Matzarakis, A. (2013), "Research on ecological design to enhance comfort in open spaces of a city (Valencia, Spain). Utility of the physiological equivalent temperature (PET)", Ecological Engineering, Vol. 57, pp. 2739.

Gould, B. (2012), "The New Zealand Tree Register - A project of the New Zealand Notable Trees Trust", Australasian Parks and Leisure, Summer, p. 5.

Gullón, P., Badland, H. M., Alfayate, S., Bilal, U., Escobar, F., Cebrecos, A., Diez, J., and Franco, M. (2015), "Assessing Walking and Cycling Environments in the Streets of Madrid: Comparing On-Field and Virtual Audits", Journal of Urban Health, Vol. 92, No. 5, pp. 923-939. 
Haines-Young, R. and Potschin-Young, M. B. (2018), "Revision of the Common International Classification for Ecosystem Services (CICES V5.1): A Policy Brief", One Ecosystem, Vol. 3, e27108, doi:10.3997/oneeco.3.27108

Hallett, V. (1989), "The Tree Register of the British Isles", Arboricultural Journal, Vol. 13, No. 2, pp. 147-149.

Hansen, G. (2014), “Design for Healthy Communities: The Potential of Form-Based Codes to Create Walkable Urban Streets", Journal of Urban Design, Vol. 19 No. 2, pp. 151-170.

Hellis (2020), "An Introduction to Visual Amenity Valuation of Trees and Woodlands", Hellis Solutions Ltd. https://www.hellis.biz/advice-centre/general/an-introduction-tovisual-amenity-valuation-of-trees-and-woodlands/

Helliwell, R. (2008), "The amenity value of trees and woodlands", Arboricultural Journal: The International Journal of Urban Forestry, Vol. 31 No. 3, pp. 161-168.

Helliwell, R. (2014), "Putting a value on visual amenity", Arboricultural Journal: The International Journal of Urban Forestry, Vol. 36 No. 3, pp. 129-139.

$\mathrm{i}$-Tree (2021), "i-Tree is a combination of science and free tools for tree management", https://www.itreetools.org/

Intramaps (2021), "A web-based enterprise GIS viewing application by TechnologyOne" https://www.technologyonecorp.com/products/spatial

Klemm, W., Heusinkveld, B. G., Lenzholzer, S., Jacobs, M. H., and Van Hove, B. (2015), "Psychological and physical impact of urban green spaces on outdoor thermal comfort during summertime in The Netherlands", Building and Environment, Vol. 83, pp. 120-128.

Koch, M., Buch-Hansen, H., and Fritz, M. (2017), "Shifting Priorities in Degrowth Research: An Argument for the Centrality of Human Needs", Ecological Economics, Vol. 138, pp. 74-81.

Laćan, I., \& McBride, J. R. (2008), “Pest Vulnerability Matrix (PVM): A graphic model for assessing the interaction between tree species diversity and urban forest susceptibility to insects and diseases", Urban Forestry and Urban Greening, Vol. 7 No. 4, pp. 291-300.

Lanza, K., and Stone, B. (2016), "Climate adaptation in cities: What trees are suitable for urban heat management?" Landscape and Urban Planning, Vol. 153, pp. 74-82.

Leach, K., Grigg, A., O'Connor, B., Brown, C., Vause, J., Gheyssens, J., Weatherdon, L, Halle, M., Burgess, N. D., Fletcher, R., Bekker, S., King, S., and Jones, M. (2019), “A common framework of natural capital assets for use in public and private sector decision making", Ecosystem Services, Vol. 36, https://doi.org/10.1016/i.ecoser.2019.100899.

Liukas, C. (2020), "How to use biochar for structured soil plant beds in urban areas", https://medium.com/carboculture/how-to-use-biochar-for-structured-soil-plantbeds-in-urban-areas-8a45108e799 
Livesley, S. J., McPherson, E. G. and Calfapietra, C. (2016), "The Urban Forest and Ecosystem Services: Impacts on Urban Water, Heat, and Pollution Cycles at the Tree, Street and City Scale", Journal of Environmental Quality, Vol. 45 No. 1, pp. 119-124.

Manetti, G. and Toccafondi, S. (2012), "The Role of Stakeholders in Sustainability Reporting Assurance", Journal of Business Ethics, Vol. 107 No. 3, pp. 363-377.

McPherson, E. G., van Doorn, N., and de Goede, J. (2016), "Structure, function and value of street trees in California, USA", Urban Forestry and Urban Greening, Vol. 17, pp. 104-115.

McPherson, E. G., and Muchnick, J. (2005), "Effects of street tree shade on asphalt concrete pavement performance", Journal of Arboriculture, Vol. 31 No. 6, pp. 303-310.

Moffat, A. J. (2016), "Communicating the benefits of urban trees: A critical review", Arboricultural Journal, Vol. 38 No. 20, pp. 64-82.

Moore, G. and Hughes, S. (2014), "The National Trust of Australia (Victoria), Register of Significant Trees: Now protecting community assets and heritage with smartphone technology", The International Journal of Urban Forestry, Vol. 36 No. 1, pp. 3-17.

Mullaney, J., Lucke, T., and Trueman, S. J. (2015), "A review of benefits and challenges in growing street trees in paved urban environments", Landscape and Urban Planning, Vol. 134, pp. 157-166

National Trust (2020a), "National Trusts of Australia Register of Significant Trees", https://trusttrees.org.au/

National Trusts of Australia (2020b), "National Trusts of Australia Register of Significant Trees: Taking Tree Measurements", National Trusts of Australia, www.trustees.org.au

National Trusts of Australia (2020c), "Practical Stewardship: Taking Care of Your Significant Tree", National Trusts of Australia, www.trustees.org.au

National Trusts of Australia (2020d), "Significant Tree Protection: Understanding Significance \& the Law", National Trusts of Australia, www.trustees.org.au

NEO (2021), Dutch environmental consultancy responsible for the national tree register ('Boomregister') https://www.neo.nl/home-int/

Pandit, R., Polyakov, M., Tapsuwan, S. and Moran, T. (2013), "The effect of street trees on property value in Perth Western Australia", Landscape and Urban Planning, Vol. 110, pp. 134-142.

Pham. T., Apparicio, P., Landry, S. and Lewnard, J. (2017), “Disentangling the effects of urban form and socio-demographic context on street tree cover: A multi-level analysis from Montréal", Landscape and Urban Planning Vol. 157, pp. 422-433.

Prescott, G. and Gronow, S. (1988), "The Welsh Redundant Building Register", Property Management, Vol. 6 No. 1, pp. 20-27.

Ramsay, J. (1991) "Parks, gardens and special trees: a classification and assessment method 
for the Register of the National Estate", Australian Government Public Service, Canberra.

Roman, L. A., Battles, J. J., and McBride, J. R. (2014), "The balance of planting and mortality in a street tree population", Urban Ecosystems, Vol. 17 No. 2, pp. 387-404.

Roman, L. A., Scharenbroch, B. C., Östberg, J. P. A., Mueller, L. S., Henning, J. G., Koeser, A. K., Sanders, J. R., Betz, D. R., and Jordan, R. C. (2017). Data quality in citizen science urban tree inventories. Urban Forestry and Urban Greening, Vol. 22, pp. 124-135.

Saarinen, N., Vastaranta, M., Kankare, V., Tanhuanpää, T., Holopainen, M., Hyyppä, J., and Hyyppä, H. (2014), “Urban-tree-criteria update using multisource single-tree inventory", Forests, Vol. 5 No. 5, pp. 1032-1052.

Salmond, J. A., Tadaki, M., Vardoulakis, S., Arbuthnott, K., Coutts, A., Demuzere, M., ... Wheeler, B. W. (2016), "Health and climate related ecosystem services provided by street trees in the urban environment", Environmental Health: A Global Access Science Source, Vol. 15 Suppl 1, https://doi.org/10.1186/s12940-016-0103-6

Sarkar, C., Webster, C., Pryor, M., Tang, D., Melbourne, S., Zhang, X., and Jianzheng, L. (2015), "Exploring associations between urban green, street design and walking: Results from the Greater London boroughs", Landscape and Urban Planning, Vol. 143, pp. 112-125.

Shackleton, S., Chinyimba, A., Hebinck, P.G.M., Shackleton, C. and Kaoma, H. (2015), "Multiple benefits and values of trees in urban landscapes in two small towns in northern South Africa", Landscape and Urban Planning, Vol. 136, pp.76-86.

Saunders, S. M., Dade, E., and Niel, K. Van. (2011), “An Urban Forest Effects (UFORE) model study of the integrated effects of vegetation on local air pollution in the Western Suburbs of Perth, WA". In 19th International Congress on Modelling and Simulation (pp. 12-16). Retrieved from http://mssanz.org.au/modsim2011

Scholz, M., Uzomah, V. C., and Al-Faraj, F. A. M. (2016), "Potential tree species for use in urban areas in temperate and oceanic climates", Heliyon, Vol. 2 No. 9 https://doi.org/10.1016/j.heliyon.2016.e00154

Tanhuanpää, T., Vastaranta, M., Kankare, V., Holopainen, M., Hyyppä, J., Hyyppä, H., ... Raisio, J. (2014), "Mapping of urban roadside trees - A case study in the tree register update process in Helsinki City", Urban Forestry and Urban Greening, Vol. 13 No. 3, pp. 562-570.

Troy, A., Grove, J. M., O’Neil-Dunne, J. P. M., Pickett, S. T. A., and Cadenasso, M. L. (2007), "Predicting opportunities for greening and patterns of vegetation on private urban lands", Environmental Management, Vol. 40, pp. 394-412.

Town of Victoria Park (2020) Significant Trees, https://www.victoriapark.wa.gov.au/Aroundtown/Environment/Significant-trees

Urgenda (2021), Newsletter January, Nieuwsbrief januari 2021 (mailchi.mp) 
Villalba, A. Pattini, A. E. and Córica, M L. (2016), “Urban trees as sunlight control elements of vertical openings in front façades in sunny climates. Case Study: Morus alba on north façade", Indoor and Built Environment, Vol. 25 No. 1, pp.279-289.

Winram, M. (2019), "Seeing the worth for the trees", Royal Institution of Chartered Surveyors Land Journal, pp. 26-27.

Zwolle (2021), "The "Groene Kaart" is the city map of the municipality of Zwolle" https://zwolle.maps.arcgis.com/apps/webappviewer/index.html?id=f178225fb81e462 f956404cdb54500e8\&webmap=ebd53688cab24f5ebc473fc6b48ce211 